\title{
Government Responsiveness under Majoritarian and (within) Proportional Electoral Systems
}

\author{
Benjamin Ferland ${ }^{*}$ \\ Benjamin Ferland, School of Political Studies, University of Ottawa, Ottawa, Canada \\ ${ }^{\star}$ Corresponding author. Email: bferland@uottawa.ca
}

(Received 18 January 2018; revised 4 October 2018; accepted 9 October 2018; First published online 7 December 2018)

\begin{abstract}
Government responsiveness to citizens' preferences is considered a sign of a wellfunctioning representative democracy. While the empirical literature has grown significantly, scholars have given less scrutiny to the conceptualization of government responsiveness and its relationship to policy/ideological congruence. We show that government responsiveness represents dynamic changes from governments in order to improve policy/ideological congruence. In addition, we consider how electoral systems influence governments' incentives to be responsive as well as their capacity to be responsive. Building on a veto player approach, we argue that government responsiveness decreases as the number of parties in cabinet increases. We examine government responsiveness to citizens' ideological preferences in 16 advanced democracies in 19802016 with respect to social spending. In line with our veto player framework, we show, first, that governments are generally more responsive under majoritarian than PR electoral systems and, second, that government responsiveness decreases under PR electoral systems as the number of parties increases in cabinet.
\end{abstract}

Keywords: political representation; government responsiveness; electoral systems; veto players

Government responsiveness to citizens' preferences has been considered a sign of a well-functioning representative democracy. As underlined by Robert Dahl (1971: 1), 'A key characteristic of democracy is the continued responsiveness of the government to the preferences of its citizens, considered as political equals'. This is in line with Hanna Pitkin's claim (1967: 232) that 'representative government must be responsive to the people'. Scholars have thus devoted a lot of attention to the policy-opinion nexus and provided considerable evidence that governments are generally responsive to shifts in citizens' preferences whether in adjusting their policies (Page and Shapiro 1983; Stimson et al. 1995), their issue priorities (Hobolt and Klemmensen 2005, 2008) or public spending (Brooks and Manza 2006; Hobolt and Klemmensen 2008; Soroka and Wlezien 2010). Moreover, while the first studies on responsiveness mostly examined the American context (Erikson et al. 1989; Page and Shapiro 1983; Stimson et al. 1995), more recent studies have 
considered government responsiveness from a cross-national perspective and the role and influence of political institutions in this process (Brooks and Manza 2006; Hobolt and Klemmensen 2008; Kang and Powell 2010; Soroka and Wlezien 2010).

While the empirical literature has grown significantly, scholars have given less scrutiny to the conceptualization of government responsiveness and especially its relationship to the concepts of policy/ideological congruence. 'Policy/ideological congruence' refers to a static state where scholars examine the distance between a government policy/position and citizens' preferences on this policy/position. A smaller (greater) distance between both positions implies more (less) congruence and, consequently, good (bad) representation. Even if policy/ideological congruence and government responsiveness are two distinct aspects of representation, the latter concept is highly connected to the former. The reason is that perfect congruence is unlikely to occur often because, as indicated by the literature on citizen-government ideological congruence, governments are generally to the left or right of their median citizen after elections (Blais and Bodet 2006; Golder and Stramski 2010; Powell 2000). Consequently, 'government responsiveness' represents the dynamic changes from governments in order to improve policy/ideological congruence.

As we detail in the next section, our definition of government responsiveness has significant implications for scholars who have examined government responsiveness to citizens' ideological preferences. The existing literature on ideological responsiveness, which we label the 'standard approach' for the sake of simplicity, claims that governments (or parties) are responsive whenever they move in the same direction as the median citizen (e.g. see the following studies: Adams 2012; Adams et al. 2006, 2009; Kang and Powell 2010; McDonald and Budge 2005). This is that a government is responsive to its citizens whenever it moves to the right when the citizens move to the right and it moves to the left whenever the citizens move to the left. We show, however, that this basic claim is problematic given that these adjustments will not always bring the government policy closer to the position of the median citizen. Our conceptualization of responsiveness and its relationship to congruence thus refines the mechanisms of responsiveness put forward in these studies.

This article also contributes to a better understanding of how political institutions, and especially electoral systems, influence levels of government responsiveness. Importantly, we argue that electoral systems influence governments' incentives to be responsive as well as their capacity to be responsive. By 'incentives', we mean the factors that may increase or decrease governments' likelihood of getting re-elected. In particular, we consider how electoral systems influence voters' capacity to sanction (reward) unresponsive (responsive) governments affecting, therefore, governments' incentives to be responsive. By 'capacity', we mean the factors that facilitate or impede governments to act on these incentives and allow them to be responsive (or not) in the first place.

This article builds on George Tsebelis's veto player approach (2002). We argue that as the number of veto players increases in a government, this undermines the government's capacity to change its policies/spending accordingly with shifts in citizens' preferences. Moreover, as the number of veto players increases in a government, this decreases voters' ability to identify the (un-)responsive parties in 
the cabinet, which decreases therefore their ability to (sanction) reward the (un-) responsive parties with the implication of decreasing governments' incentives to be responsive. Our theory leads us to expect greater levels of government responsiveness under majoritarian electoral systems than proportional representation (PR) electoral systems, given that the number of parties in cabinet is generally greater under PR systems (formation of coalition governments most of the time) than under majoritarian systems (formation of single-party majority governments most of the time). Our theory also leads us to expect some variations in government responsiveness within PR electoral systems. In particular, we expect governments with fewer veto players to be more responsive than governments with several veto players.

We test our theory by examining advanced democracies over the post-war period. Following previous studies on government responsiveness (Brooks and Manza 2006; Kang and Powell 2010; McDonald and Budge 2005), we test our claims with respect to the area of social spending. Especially, we examine whether governments adjust social spending accordingly with changes in citizens' ideological preferences, as measured with survey data from the Comparative Study of Electoral Systems (CSES) and several national election studies. With regard to the impact of electoral systems, our results show, as expected, that governments adjust their spending accordingly with citizens' ideological preferences only under majoritarian systems or under PR systems that produce single-party governments. As predicted, but contrary to the claim in the literature, these responsive governments only follow movements of the median citizen that are away from their position - not otherwise. The results of the article thus contribute to the debate about which electoral system fosters government responsiveness between government policies and citizens' preferences. Overall, we provide significant evidence of the advantages of majoritarian systems in making government outputs respond to citizens' preferences.

\section{Conceptualizing government responsiveness to and congruence with citizens' preferences}

'Perfect congruence' between a government policy and citizens' preferences represents a static state where the government policy/position perfectly matches the preference of the median citizen (see Figure 1a). Following the existing literature, we take the preference of the median citizen as the indication of citizens' preferences (Cox 1997; Huber and Powell 1994). Perfect congruence is generally conceived as one of the core objectives of the democratic policymaking process (Dalton et al. 2011; Powell 2004; Przeworski et al. 1999). Importantly, scholars claimed that politicians face significant electoral incentives to implement policies close to citizens' preferences (Erikson et al. 2002; Mansbridge 2003; Mayhew 1974; Soroka and Wlezien 2010; Stimson et al. 1995), especially mainstream parties (Adams et al. 2006; Ezrow et al. 2011).

Conversely, a situation of incongruence is displayed in Figure 1b, which indicates a mismatch between the position of the median citizen and the government policy (see Golder and Stramski 2010 for different conceptualizations of congruence). Given a situation of incongruence, government responsiveness represents 
(a)

Situation of perfect congruence

Government

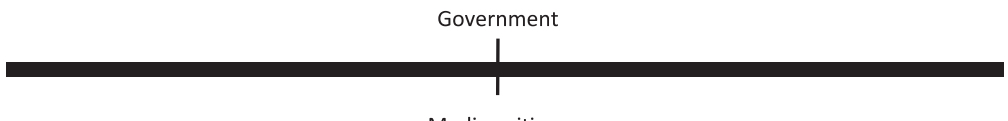

Median citizen

(b)

Situation of incongruence

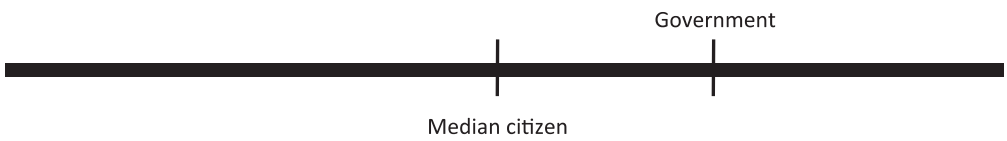

(c)

Government responsiveness

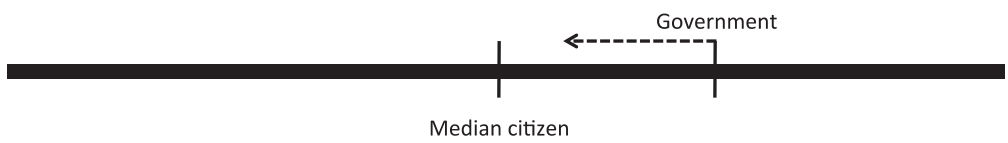

Figure 1. Conceptualizing (In)Congruence and Responsiveness

an action taken by the government to foster congruence between the government policy and the preference of the median citizen as shown by the dashed arrow in Figure 1c. Congruence is thus a static state where we examine the distance between a government policy and the preference of the median citizen on a policy (as in Figure 1b), while responsiveness involves a dynamic change from the government in order to foster congruence (as in Figure 1c) and which could ultimately lead to perfect congruence (as in Figure 1a).

Situations of perfect congruence, however, are rare (Blais and Bodet 2006; Golder and Stramski 2010; Powell 2000) and citizens may change as well their preferences (Durr 1993; Soroka and Wlezien 2010). Therefore, the question is, given a situation of incongruence, does a government change its policy in a way that makes it more congruent with the preference of the median citizen and thus responsive? There are two possibilities to consider with respect to possible changes in the preference of the median citizen. First, the preference of the median citizen may move away from the government policy, with the consequence of decreasing congruence. Second, the preference of the median citizen may move towards the government policy, with the consequence of increasing congruence. ${ }^{1}$

According to the existing literature on government responsiveness to citizens' ideological preferences (Adams et al. 2006, 2009; Kang and Powell 2010; McDonald and Budge 2005), responsive governments should always move (their policy position and public spending) in the same direction that the median citizen moves: if the median citizen moves left, the government should move left, while if the median citizen moves right, the government should move right.

A shortcoming of the standard approach, however, is that not all government responses lead to an increase in congruence. As displayed in Figure 1 (b or c), if the median citizen moves left, the government should move left and this movement will increase congruence. However, if the median citizen moves right towards the 
government and the government also moves right, this movement will not increase congruence with the median citizen. The problem is that the standard approach omits to consider whether the preference of the median citizen is initially to the left or right of the government and, therefore, whether the median citizen moves towards or away from the government.

Conversely, our predictions all lead to an improvement in congruence. This is that government responsiveness implies a dynamic change from the government in order to foster congruence. First, if the preference of the median citizen is moving to the left away from the government, the government is responsive to citizens' preferences if it changes its policy to the left towards the preference of the median citizen. The more the government changes its policy close to the new position of the median citizen, the more responsive the government. This prediction is consistent with the prediction of the standard approach. Second, if the preference of the median citizen is moving to the right towards the government policy, the government is responsive to citizens' preferences if it changes its policy to the left towards the preference of the median citizen. This prediction is different from the prediction of the standard approach (see the online appendix for details and several figures supporting these predictions).

Two key points appear from our predictions. First, the direction of a government's movement to be responsive depends on whether the median citizen is to the left or right of the government. If the median citizen is to the left and moves left, the government should move left, but if the median citizen is to the right and moves left, the government should move right - and vice versa. ${ }^{2}$ Second, a situation where the preference of the median citizen is moving away from the government policy is detrimental to congruence while a situation where the preference of the median citizen is moving towards the government policy is beneficial. Governments may view beneficial or harmful movements by the median citizen in different ways. In effect, it is potentially costly for a government not to answer a change in the position of the median citizen away from its position, while this is not necessarily the case when the median citizen is moving towards its position actually a change from the median citizen towards the government position might be electorally beneficial. Consequently, the magnitude and the likelihood of the change in policy should be significantly greater when the median citizen is moving away from the government than when the median citizen is moving towards the government. We thus propose the following hypotheses:

Hypothesis 1: (The moving-away hypothesis) When the position of the median citizen is moving to the left (right) away from the position of the government to her right (left), the government will adjust significantly - its spending upwards (downwards).

Hypothesis 2: (The moving-closer hypothesis) When the position of the median citizen is moving to the left (right) towards the position of the government to her left (right), the government will adjust its spending downwards (upwards).

These hypotheses are also consistent with spatial models of party competition that predict convergence on the median voter for parties that have vote-seeking 
motivations (Downs 1957; Enelow and Hinich 1984). We acknowledge, however, that alternative models which incorporate policy-seeking motivations indicate that parties do not always converge on the median voter and may even move away from the median citizen (Wittman 1977, 1983). While this is a possibility, we note that parties forming governments are generally mainstream parties that place greater emphasis on vote-seeking than policy-seeking objectives (D'Alimonte 1999; Kitschelt 1994). On the other hand, the prediction that some parties will not converge on the median voter is more suited to the behaviour of niche parties (seldom in government) that have been characterized as mostly policy-oriented and not inclined to be responsive to the median voter (Ezrow et al. 2011). For these reasons, we assume that our hypotheses are mostly supported by predictions of spatial models of party competition given the type of parties that generally form governments. Importantly, we will distinguish in the next analyses whether governments move closer or away from the median citizen and thus confirm (or not) these predictions.

\section{Government responsiveness and the impact of electoral systems}

Scholars have recently begun examining the impact of electoral systems on government responsiveness to citizens' preferences. Until now, they offered contradictory expectations about whether government responsiveness should be greater under majoritarian or PR electoral systems in considering mostly the electoral incentives provided by each electoral system. For example, Sara Hobolt and Robert Klemmensen (2008) assume that governments under majoritarian systems have more incentives to be responsive to local interests and pivotal districts than to the median voter, whereas governments under PR systems have more incentives to be responsive to the wider public. Hobolt and Klemmensen (2008) found that government responsiveness (at least in respect of governments' annual speeches outlining the government's policy priorities) is greater in Denmark (PR system) than in Britain (majoritarian system). Shin-Goo Kang and G. Bingham Powell (2010) also expect government responsiveness to be greater under PR systems than majoritarian systems but for a different reason. According to Kang and Powell (2010), government responsiveness to citizens' preferences should be greater under PR systems than majoritarian systems due to the greater citizen-government ideological congruence observed in PR systems for their period of study. In examining advanced democracies over the post-war period, they show that governments adjust their welfare spending accordingly with shifts in the position of the median voter - shifts to the left (right) influence welfare spending upwards (downwards) - but they found similar levels of government responsiveness under majoritarian and PR systems (Kang and Powell 2010).

In disagreement with Kang and Powell (2010) and Hobolt and Klemmensen (2008), Christopher Wlezien and Stuart Soroka (2012) expect governments in majoritarian systems to be more responsive since it is easier for a single-party government to react to changes in public opinion and because the electoral incentives are greater due to a greater seats-votes elasticity. They also provided some evidence of greater government responsiveness under majoritarian systems. Wlezien and Soroka (2015) detailed afterwards their expectations in considering 
the electoral and organizational mechanisms of dynamic representation (i.e. representation between elections). Wlezien and Soroka (2015) emphasized the distinction between coalition governments (PR systems) and single-party majority governments (majoritarian systems), which have different incentives to be responsive but also differ in terms of the coordination cost that confronts them in the face of a changing public opinion. Consistent with their prior work, they expected better dynamic representation under majoritarian systems than proportional electoral systems but did not directly test this expectation.

Overall, evidence about the impact of electoral systems on government responsiveness is mixed while the expectations are mostly contradictory. Importantly, scholars - except Wlezien and Soroka (2015) - did not distinguish how electoral systems affect governments' incentives to be responsive from their capacity to be responsive. This shortcoming is problematic given that in order to take advantage of the electoral incentives to be responsive, governments must have the capacity to act on these incentives in the first place. It is thus important to consider both types of factors when examining the impact of electoral systems on government responsiveness. In the next section, we address these shortcomings.

\section{Veto players and government responsiveness}

Building on the work of Wlezien and Soroka (2015), we assume that two conditions are necessary for government responsiveness to occur. First, a government must have the capacity to change the status quo - that is, the actual policy. Second, a government must have the incentives to change the status quo in accordance with citizens' preferences. In order to understand the impact of electoral systems on government responsiveness we must, therefore, examine how electoral systems influence each of these factors. We believe that Tsebelis's theory of veto players (2002) is a useful theoretical approach for developing our expectations regarding the impact of electoral systems on government responsiveness since it relates to these two conditions. Tsebelis (2002: 37) defines a veto player as an individual or a collective group whose agreement is necessary in the decision-making process for changing policy outcomes. Tsebelis shows that as the number of veto players increases, policy stability is enhanced - or at least is not weakened (first condition). Following previous studies (Bawn 1999; Ha 2008; Tsebelis 2002; Tsebelis and Chang 2004), we assume that each party in a government represents a partisan veto player. This is reasonable given that, ultimately, a party in government always has at its disposal the threat of leaving the coalition in order to turn down a proposed policy change. Consequently, as the number of parties increases in cabinet, it reduces the government's capacity to change the status quo and consequently to be responsive to citizens' preferences. This is that governments' capacity to be responsive declines as the number of parties increases in cabinet.

In addition, a veto player framework has some implications for the electoral incentives that governments have to be responsive (second condition). This is because the number of veto players in cabinet also affects the extent to which governments are accountable to voters and consequently their incentives to be responsive. The underlying assumption in studies of government responsiveness is that responsive governments might be rewarded electorally while unresponsive 
governments might be harmed electorally. For that to occur, however, voters must have the ability to identify the (un-)responsive parties in cabinet in order to (punish) reward them accordingly. If voters are unable to do so this decreases government incentives to be responsive. Government responsiveness should thus be greater when clarity of responsibility is maximized - that is, politicians have greater electoral incentives to be responsive when the political system makes them clearly accountable for their actions. In effect, the number of parties in government affects negatively the clarity of responsibility among the coalition partners and the extent to which, therefore, these parties are accountable to voters (Fisher and Hobolt 2010; Powell and Whitten 1993). Indeed, the fact that a coalition of parties is responsible for the overall government direction makes it difficult for voters to assign the responsibility of each party separately - parties that are held accountable separately at election time. The veto player approach thus indicates that, as the number of veto players increases in a cabinet, governments have fewer incentives to be responsive because the threat (benefit) of being sanctioned (rewarded) for unresponsive (responsive) actions declines.

Overall, the veto player approach provides clear expectations about the conditions under which governments have the capacity and the incentives to change the status quo in accordance with changes in citizens' preferences. Given that governments involve a greater number of veto players under PR electoral systems (coalition governments generally) than under majoritarian systems (single-party majority governments generally), it should be harder for these governments to respond to changes in citizens' preferences. In addition, the veto player approach is useful in making predictions about how government responsiveness varies within PR systems. Under PR systems, we assume that governments having more parties should be less responsive to changes in citizens' preferences than cabinets with a smaller number of parties. Overall, we expect the following hypotheses: ${ }^{3}$

$\begin{aligned} & \text { Hypothesis 3: } \text { (The majoritarian hypothesis) Government responsiveness is } \\ & \text { greater under majoritarian systems than under PR systems. }\end{aligned}$

Hypothesis 4: (The number-of-parties hypothesis) Under PR systems, government responsiveness decreases as the number of parties in government increases.

\section{Data and measurement}

In order to test the previous hypotheses, we need data that provide the positions of citizens and governments on a policy dimension, over time and across countries. The CSES meets this objective given that it gathers citizens' preferences on the leftright ideological scale as well as their perception of each party position over the 1996-2016 period in several countries (modules 1 to 4). One of the advantages of the CSES data is also that the surveys are implemented approximately at the same time, after national elections, which allows us to examine government responsiveness from approximately the same starting point - that is, when governments are formed. In order to increase the number of consecutive elections for measuring changes in citizens' preferences we also gather for each country all the national 
election studies where it was possible to locate citizens' and parties' positions on a left-right ideological scale.

Testing our hypotheses with respect to the left-right ideological scale is interesting given that the left-right cleavage has represented a meaningful political dimension in advanced industrial democracies throughout the post-war period (Dalton et al. 2011; McDonald and Budge 2005; Powell 2000). We recognize that new dimensions of political competition have arisen in recent years (Bakker et al. 2012; Kriesi et al. 2008) but the left-right ideological dimension remains an important dimension that still structures party systems and vote choice in advanced democracies (Dalton et al. 2011; Jessee 2012; Joesten and Stone 2014). In particular, the left-right scale has been shown to be one of the most compelling measures for summarizing citizens' preferences on different welfare/social policy issues (Dalton et al. 2011; Huber 1989) which is directly associated to the government policies that we analyse - social spending. In the next empirical analyses, we thus follow previous studies (Kang and Powell 2010; McDonald and Budge 2005) which showed that changes in citizen preferences as measured on a left-right ideological dimension are generally correlated to the adjustments that governments make to their social spending. ${ }^{4}$

Overall, the study includes 16 advanced democracies over the 1980-2016 period. The countries under majoritarian systems are: Australia, Canada, France, New Zealand (pre-1996) and the UK. The countries under PR systems are: Austria, Denmark, Finland, Germany, Iceland, Ireland, the Netherlands, New Zealand (post-1995), Norway, Spain, Sweden and Switzerland (see Table A in the online appendix for the list of elections). ${ }^{5}$

\section{Measuring change in social spending}

The social expenditure database provided by the OECD is used to measure shifts in government spending. Social spending includes different policy domains such as unemployment, housing, family, old age, etc. The dependent variable is the change in public social expenditure as a percentage of a country GDP between two elections - that is, between the year at the beginning of a government mandate and the year at the end of a government mandate $\left(\right.$ election $_{\mathrm{t}-1}$ and election $\left.\mathrm{n}_{\mathrm{t}}\right){ }^{6}$ The rationale for this interval is discussed in the next section and relates to the period when citizens' and governments' positions are measured. Overall, it appears that the average absolute change in social spending over the lifetime of governments is slightly greater under PR systems (1.66 points of percentage of GDP) than under majoritarian systems (1.03 points of percentage of GDP) - a difference-in-means test indicates that the difference is statistically significant at the 0.1 level.

\section{Measuring change in the position of the median citizen}

In order to locate the positions of the median citizen and government for each country, we use data from the CSES project. The question used in the CSES data set to locate respondents' left-right position is: 'In politics people sometimes talk of left and right. Where would you place yourself on a scale from 0 to 10 where 0 means the left and 10 means the right?' For each election survey we compute the 
median position of all respondents. ${ }^{7}$ Respondents were also asked to locate each party on a 0-10 left-right scale. We thus compute the government position based on each party's median position weighted by its share of cabinet portfolios. We use the European Journal of Political Research Political Data Yearbook to determine each party's share of cabinet portfolios. For the pre-1991 period, we use Swank's data set (Swank 2006). ${ }^{8}$ Note that we exclude governments when there was a change in cabinet during the government mandate (a change in the coalition members) as it is not possible to assess whether the median citizen is moving towards or away from these new governments given our research design. ${ }^{9}$ In order to increase the number of consecutive elections, we also include all national election studies that asked respondents to locate themselves and each party on a $0-$ 10 left-right scale. Overall, we have 15 pairs of consecutive elections under majoritarian systems and 40 under PR systems. ${ }^{10}$

The argument to be tested is that government responsiveness is contingent on whether the median citizen is moving towards or away from a government to her left (right). Accordingly, two variables are needed to capture changes in the position of the median citizen: closer $\Delta$ median citizen (changes towards governments) and away $\Delta$ median citizen (changes away from governments). To compute these variables, we need first to compute $\Delta$ median citizen, which is the difference between the position of the median citizen at the end of a government mandate $(\mathrm{t})$ and the beginning of a government mandate $(\mathrm{t}-1)$. Our empirical strategy is thus to examine whether governments adjust their social spending over their mandate - that is, between the beginning and the end of their term in office - in response to changes in the position of the median citizen over the same period. We recognize that a better research design would be to examine the effect of $\Delta$ median citizen on $\Delta$ social spending at the year level but, to our knowledge, there are no data that provide the position of the median citizen annually and cross-nationally.

Closer $\Delta$ median citizen and away $\Delta$ median citizen are computed as follows:

Away $\Delta$ median citizen $=\Delta$ median citizen $\times$ disadvantageous

Closer $\Delta$ median citizen $=\Delta$ median citizen $\times(1-$ disadvantageous $)$

where disadvantageous is a dummy variable that indicates whether $\Delta$ median citizen is away from the government (coded 1) - when the median citizen to the right (left) of the government moves to the right (left) - or towards the government (coded 0) - when the median citizen to the right (left) of the government moves to the left (right). It is important to underline that closer and away $\Delta$ median citizen are minor modifications of the variable $\Delta$ median citizen and that they encompass all the information provided in the latter.

Our expectation is that the coefficient of closer $\Delta$ median citizen will be positive, indicating that when the median citizen is moving to the left (right) towards a government to her left (right), the government decreases (increases) its social spending. ${ }^{11}$ On the other hand, the estimated coefficient of away $\Delta$ median citizen should have a negative sign indicating that when the median citizen is moving to the left (right) away from a government to her right (left), the government increases (decreases) its social spending. 
Overall, governments under majoritarian and PR systems are facing similar demands from their citizens with respect to shifts in the position of the median citizen. The latter are generally disadvantageous to governments $(67 \%$ and $73 \%$ of the cases under majoritarian and PR systems, respectively) and of moderate magnitude. However, we note that changes in the position of median citizen away from governments in PR systems are generally more disadvantageous to governments ( 1.71 points) than under majoritarian systems ( 0.71 points) - the difference is statistically significant at the 0.1 level. The difference in the average change towards the government under majoritarian (0.53) and PR (0.53) systems is not statistically significant.

\section{Control variables}

A number of factors that may be correlated with our independent variables and $\Delta$ social spending must be controlled for. For example, it is necessary to include variables such as $\Delta$ unemployment and $\Delta$ proportion of the population over 65 years old since they directly affect social spending (Franzese 2002: 76) and they may affect citizens' preferences on social spending. Moreover, given that $\Delta$ social spending is expressed as a proportion of GDP, we also control for a country's GDP at the beginning of the mandate and the $\Delta G D P$ between elections. The data for these control variables come from the OECD statistics database. ${ }^{12}$ We also control for the level of social spending at the beginning of the mandate as it may influence citizens' preferences on social spending as well as governments' capacity to change social spending. For example, high levels of social spending may induce citizens to express a preference for a decrease in social spending - as predicted by the thermostatic model (Soroka and Wlezien 2010) - while it may also hamper governments' capacity to increase social spending even further. We also include the positions of the median citizen and government at the beginning of the mandate because these variables may also influence $\Delta$ social spending and we want to assure that the impact of closer and away $\Delta$ median citizen holds wherever the median citizen and government are at the beginning of the mandate.

\section{Testing the moving-away and moving-towards hypotheses}

In Table 1, we present the results of OLS regressions with fixed-effects for each country: the within regression estimator. Country fixed-effects control for the omission of time-invariant variables (essentially country-specific variables) such as federalism and bicameralism. It is important to control for these types of variables with fixed-effects given that not doing so may bias the impact of the independent variables. The introduction of country fixed-effects also relaxes the assumption that a government/median citizen position on the left-right ideological scale represents exactly the same substantive position cross-nationally. However, it does not affect the assumption that a one-unit change on the left-right scale represents the same distance across countries. Note that country fixed-effects may be problematic for testing the majoritarian hypothesis - we discuss this issue below. 
Table 1. The Impact of Closer/Away $\Delta$ Median Citizen on $\Delta$ Social Spending

(1) Standard

$\Delta$ median citizen

Closer $\Delta$ median citizen

Away $\Delta$ median citizen

Controls

Constant

Observations

R-squared within model
$-0.08(0.06)$

$81(8.09)^{*}$
(2) Our model

$-0.12(0.19)$

$-0.04(0.08)$

Yes

$15.26(8.38)^{\star}$

$\begin{array}{cc}55 & 55 \\ 0.72 & 0.73\end{array}$

0.73

Notes: Robust standard errors in parentheses. ${ }^{*} p<0.10,{ }^{\star \star} p<0.05,{ }^{* * *} p<0.01$. The dependent variable is the change in social spending between two elections as a percentage of a country GDP. The analysis includes 16 countries over the 19802016 period. Controls are not displayed. See Table B in the online appendix for the full table including control variables.

In Table 1, we test the moving-away and moving-towards hypotheses and examine the impact of closer and away $\Delta$ median citizen on $\Delta$ social spending. We estimate the following specification: ${ }^{13}$

$$
\begin{aligned}
\Delta \text { social spending }= & \mathrm{b}_{1}+\mathrm{b}_{2}[\text { closer } \Delta \text { median citizen }] \\
& +\mathrm{b}_{3}[\text { away } \Delta \text { median citizen }]+\mathrm{b}_{4}[\text { disadvantageous }]+\text { controls }
\end{aligned}
$$

To support our hypotheses, recall that closer $\Delta$ median citizen and away $\Delta$ median citizen should have a positive and negative impact, respectively. Given that our hypotheses are in opposition with the claim of the standard approach that governments must adjust their spending upwards (downwards) whenever the median citizen is moving to the left (right), we also compare the impacts of our variables of interest with the impact of $\Delta$ median citizen. If the standard approach is accurate $\Delta$ median citizen will have a negative effect on $\Delta$ social spending.

In column (1) of Table 1, we present the results of the impact of $\Delta$ median citizen. The coefficient of $\Delta$ median citizen is negative $(-0.08)$ as predicted by the standard approach but the impact is not statistically significant at the 0.1 level. The second step is to examine the impact of closer and away $\Delta$ median citizen on $\Delta$ social spending. The results are presented in column (2) and do not support our Hypotheses 1 and 2 . The coefficients of closer $(-0.12)$ and away $\Delta$ median citizen $(-0.04)$ are both negative and they do not reach the conventional level of statistical significance. These initial results run against our main hypotheses but they may, however, mask effects heterogeneity across majoritarian and PR electoral systems. We address this possibility and test the majoritarian hypothesis in the next section.

\section{Testing the majoritarian hypothesis}

In Table 2, we test the majoritarian hypothesis. Recall that we expect government responsiveness to be greater under majoritarian systems than PR systems. To be consistent with our hypothesis, the impact of closer and away $\Delta$ median citizen should be, respectively, positive and negative under both electoral systems but the magnitude of these effects should be greater under majoritarian systems than PR 
Table 2. The Conditioning Impact of Electoral Systems

\begin{tabular}{|c|c|c|c|c|}
\hline & (1) Standard & (2) Our model & (3) Standard & (4) Our model \\
\hline$\Delta$ median citizen & $-0.17(0.09)^{\star}$ & & $-0.11(0.10)$ & \\
\hline$\Delta$ median citizen $\times \mathrm{PR}$ & $0.11(0.10)$ & & $0.05(0.11)$ & \\
\hline Closer $\Delta$ median citizen $\times$ MAJ & & $0.33(0.26)$ & & $0.02(0.17)$ \\
\hline Closer $\Delta$ median citizen $\times \mathrm{PR}$ & & $-0.12(0.39)$ & & $-0.15(0.29)$ \\
\hline Away $\Delta$ median citizen $\times$ MAJ & & $-0.49(0.15)^{\star \star \star}$ & & $-0.35(0.17)^{\star \star}$ \\
\hline Away $\Delta$ median citizen $\times \mathrm{PR}$ & & $-0.04(0.09)$ & & $-0.09(0.09)$ \\
\hline Controls & Yes & Yes & Yes & Yes \\
\hline Constant & $19.69(9.28)^{*}$ & $16.71(9.88)$ & $2.00(4.17)$ & $2.57(4.31)$ \\
\hline Observations & 55 & 55 & 55 & 55 \\
\hline R-squared within model & 0.75 & 0.77 & 0.69 & 0.65 \\
\hline Model & $\mathrm{FE}$ & $\mathrm{FE}$ & RE & RE \\
\hline
\end{tabular}

Notes: Robust standard errors in parentheses. ${ }^{\star} p<0.10,{ }^{\star \star} p<0.05,{ }^{\star \star \star} * 0<0.01$. The dependent variable is the change in social spending between two elections as a percentage of a country GDP. The analysis includes 16 countries over the 1980-2016 period. Controls are not displayed. See Table C in the online appendix for the full table including control variables.

systems. To test the majoritarian responsiveness hypothesis we estimate the following specification:

$\Delta$ socialspending $=\mathrm{b}_{1}+\mathrm{b}_{2}[$ closer $\Delta$ mediancitizen $\times P R]+\mathrm{b}_{3}[$ away $\Delta$ mediancitizen $\times P R]$ $+\mathrm{b}_{4}[$ closer $\Delta$ mediancitizen $\times M A J]+\mathrm{b}_{5}[$ away $\Delta$ mediancitizen $\times M A J]$ $+\mathrm{b}_{6}[$ disadvantageous $]+\mathrm{b}_{7}[$ disadvantageous $\times P R]+\mathrm{b}_{8}[P R]+$ controls,

where $P R$ is a dummy variable coded 1 for $P R$ electoral systems and 0 for majoritarian systems while $M A J$ is a dummy variable coded 0 for PR electoral systems and 1 for majoritarian systems. Given that disadvantageous is a constitutive term of closer and away $\Delta$ median citizen it is also necessary to interact disadvantageous with $P R .^{14}$

Note that this specification follows Thomas Brambor et al.'s (2006: see equation $7,69-70)$ alternative specification when dealing with a discrete modifying variable (see also Wright 1976). The main advantage of this specification is to ease the interpretation of the results (see Ferland 2017a for a more detailed discussion of the two approaches). In Table 2, the impact of closer and away $\Delta$ median citizen on $\Delta$ social spending under majoritarian and PR electoral systems, respectively, are provided directly from the coefficients displayed in columns (2) and (4). In particular, closer $\Delta$ median citizen $\times M A J$ indicates the effect of a change in the position of the median citizen towards the government position under majoritarian systems; closer $\Delta$ median citizen $\times P R$ indicates the effect of a change in the position of the median citizen towards the government position under PR systems; away $\Delta$ median citizen $\times M A J$ indicates the effect of a change in the position of the median citizen away from the government position under majoritarian systems; and away $\Delta$ median citizen $\times P R$ indicates the effect of a change in the position of the median citizen away from the government position under PR systems. To get these corresponding effects in the 'standard approach' to interaction models, we would need to add up several coefficients. Importantly, the results of both approaches are 
statistically the same (see Tables $\mathrm{E}$ and $\mathrm{F}$ in the appendix for the replication of the results with the standard approach).

In column (1) of Table 2, we first test the claim of the standard approach and present the impacts of $\Delta$ median citizen on $\Delta$ social spending under majoritarian $(\Delta$ median citizen) and $\mathrm{PR}$ systems $(\Delta$ median citizen $\times P R)$. It appears that $\Delta$ median citizen has a negative impact on $\Delta$ social spending under majoritarian systems. This is indicated by the coefficient of $\Delta$ median citizen in column (1), which equals -0.17 and is statistically significant at the 0.1 level. This is consistent with predictions of scholars claiming that governments must increase (decrease) spending whenever the median citizen is moving to the left (right). However, this relationship does not appear under PR systems. In column (1), the effect of $\Delta$ median citizen in PR systems is given by the sum of the coefficients of $\Delta$ median citizen $(-0.17)$ and $\Delta$ median citizen $\times P R(0.11)$ which equals -0.06 and is not statistically significant at the 0.1 level as indicated by a Wald test. The results in column (1) - at least with respect to governments under majoritarian systems - are thus consistent with the predictions of the standard approach, which claims that governments should increase (decrease) social spending whenever the median citizen is moving to the left (right).

Note that even if the results in column (1) of Table 2 are in line with the standard approach we must keep in mind that the impact of $\Delta$ median citizen in column (1) actually blurs the impact of closer and away $\Delta$ median citizen on $\Delta$ social spending. In column (2), we distinguish these impacts, respectively, under majoritarian and PR systems. In column (2), the results support the majoritarian hypothesis when it comes to the impact of away $\Delta$ median citizen: away $\Delta$ median citizen $\times M A J$ has a negative impact $(-0.49)$ on $\Delta$ social spending which is statistically significant at the 0.01 level while the impact of away $\Delta$ median citizen $\times P R$ is close to zero and not statistically significant $(-0.04)$. This indicates, as predicted, that as the median citizen is moving to the right (left) by one unit on the left-right scale away from the government position, under majoritarian systems social spending decreases (increases) by 0.49 points of percentage of a country's GDP. Conversely, the fact that the coefficient of away $\Delta$ median citi$z e n \times P R(-0.04)$ is not statistically different from 0 indicates that governments under PR systems do not respond to changes in the position of the median citizen that are away from government positions. Moreover, a Wald test confirms that the difference of 0.45 points between the coefficients of away $\Delta$ median citizen $\times$ MAJ $(-0.49)$ and away $\Delta$ median citizen $\times P R(-0.04)$ is statistically significant at the 0.01 level.

In column (2) it appears, however, that governments under majoritarian systems are not more responsive than governments under PR systems when the median citizen is moving towards the government position. While closer $\Delta$ median citizen $\times$ MAJ (0.33) is positive and in the expected direction in column (2), it fails to reach the conventional level of statistical significance. Moreover, closer $\Delta$ median citizen $\times P R(-0.12)$ is negative and not statistically significant at the 0.1 level. The difference between these two coefficients is not statistically significant, as indicated by a Wald test. Against our expectation, these results indicate that governments under majoritarian and PR systems do not adjust their social spending downwards 
(upwards) when the median citizen to the right (left) of the government is moving to the left (right) towards the government.

Even if these results associated with closer $\Delta$ median citizen do not support our expectations they add some nuance to the validity of the standard approach in column (1). In effect, if governments were adjusting their social spending as predicted by the standard approach, both the coefficients of away $\Delta$ median citi$z e n \times M A J$ and closer $\Delta$ median citizen $\times M A J$ in column (2) would have been negative and statistically significant. This would have been consistent with the negative impact of $\Delta$ median citizen displayed in column (1). The fact, therefore, that only away $\Delta$ median citizen $\times M A J$ is negative and statistically significant while not closer $\Delta$ median citizen $\times$ MAJ indicates that governments under majoritarian systems do not adjust their social spending in the manner predicted by the standard approach. The negative impact of $\Delta$ median citizen in column (1) appears to be driven mostly by those governments under majoritarian systems that are being responsive to shifts in the position of the median citizen that are away from their position.

We must also underline that the results associated with the impact of closer $\Delta$ median citizen - even if not directly consistent with the moving-closer hypothesis are actually more consistent with our framework of government responsiveness than with the standard approach. As noted above, changes in the position of the median citizen towards governments are beneficial to governments. The fact that governments are not responsive to these changes (in keeping social spending at about the same level) is, therefore, more beneficial to congruence than if governments were moving social spending in the same direction of the median citizen as predicted by the standard approach.

To validate these results further, we replicate the results of columns (1) and (2) with a random-effects model in columns (3) and (4) and find substantively similar results. Overall, the results displayed in Table 2 support the majoritarian hypothesis with respect to the impact of away $\Delta$ median citizen and indicate that governments under majoritarian systems are more responsive to changes in the position of the median citizen than governments under PR systems when these changes are away from the government position.

\section{Government responsiveness within PR systems}

The previous results indicate that governments under PR systems are not responsive to shifts in the position of the median citizen whether these changes are towards or away from the government position. As we argued above, however, it is still possible that government responsiveness occurs under certain types of governments in PR systems. In particular, we argued that government responsiveness under PR systems should decrease as the number of parties in government increases (Hypothesis 4). In order to test this hypothesis under PR systems, we estimate the following specifications (the model number corresponds to the column in Table 3). Note that we test our hypotheses in two separate models because of the small number of observations that we have in PR systems (40) and the 
several interaction effects which reduce significantly the degrees of freedom.

(model 2) $\Delta$ social spending $=\mathrm{b}_{1}+\mathrm{b}_{2}[$ closer $\Delta$ median citizen $]$

$+\mathrm{b}_{3}[$ closer $\Delta$ median citizen $\times \#$ of parties $]+\mathrm{b}_{4}[\#$ of parties $]$

$+\mathrm{b}_{5}[$ away $\Delta$ median citizen $]+\mathrm{b}_{6}[$ disadvantageous $]+\mathrm{b}_{7}[$ disadvantageous $]$

+ controls

(model 3$) \Delta$ social spending $=\mathrm{b}_{1}+\mathrm{b}_{2}[$ away $\Delta$ median citizen $]$

$+\mathrm{b}_{3}[$ away $\Delta$ median citizen $\times \#$ of parties $]+\mathrm{b}_{4}[\#$ of parties $]$

$+\mathrm{b}_{5}[$ closer $\Delta$ median citizen $]+\mathrm{b}_{6}[$ disadvantageous $]$

$+\mathrm{b}_{7}[$ disadvantageous $\times \#$ of parties $]+$ controls

where \# of parties is the number of parties in cabinet. We expect the marginal effect of away $\Delta$ median citizen (closer $\Delta$ median citizen) to be negative (positive) and statistically significant when \# of parties is at its minimum value (one). As \# of parties increases, the marginal effect of away $\Delta$ median citizen (closer $\Delta$ median citizen) should decrease in magnitude and become not different from 0 approximately at the maximum value of \# of parties.

In Table 3, we test the number-of-parties hypothesis (columns 2 and 3) and present the results of OLS regressions with fixed-effects for each country. In column (1), we also present the results of the standard approach with the interaction between $\Delta$ median citizen and \# of parties. It appears in column (1) that none of the variables has a statistically significant impact on $\Delta$ social spending. In column (2), the coefficient of closer $\Delta$ median citizen is negative $(-0.89)$ while its interaction effect with \# of parties has a positive effect $(0.59)$ statistically significant at the 0.1 level - which is against our hypothesis. However, the examination of the marginal effects of closer $\Delta$ median citizen in column (2) reveals no statistically significant impact as \# of parties increases in cabinet (the graphical results are not displayed).

Table 3. The Impact of Closer/Away $\Delta$ Median Citizen on $\Delta$ Social Spending under PR Systems

\begin{tabular}{lccc}
\hline & (1) Standard & $\begin{array}{c}\text { (2) Our model } \\
\text { closer } \Delta\end{array}$ & $\begin{array}{c}\text { (3) Our model } \\
\text { away } \Delta\end{array}$ \\
\hline $\begin{array}{l}\Delta \text { median citizen } \\
\text { Closer } \Delta \text { median citizen }\end{array}$ & $-0.26(0.15)$ & $-0.89(0.56)$ & $-0.05(0.41)$ \\
Away $\Delta$ median citizen & $0.04(0.14)$ & $-0.44(0.15)^{\star *}$ \\
$\begin{array}{l}\Delta \text { median citizen } \times \# \text { of parties } \\
\text { Closer } \Delta \text { median citizen } \times \# \text { of parties }\end{array}$ & $0.09(0.07)$ & $0.59(0.28)^{*}$ & $0.21(0.07)^{\star *}$ \\
Away $\Delta$ median citizen $\times \#$ of parties & Yes & Yes \\
Controls & $35.47(10.58)^{* \star *}$ & $28.58(6.41)^{\star \star *}$ & $41.47(10.28)^{\star * *}$ \\
Constant & 40 & 40 & 40 \\
\hline $\begin{array}{l}\text { Observations } \\
\text { R-squared within model }\end{array}$ & 0.81 & 0.82 & 0.83 \\
\hline
\end{tabular}

Notes: Robust standard errors in parentheses. ${ }^{\star} p<0.10,{ }^{\star \star} p<0.05,{ }^{\star \star \star} p<0.01$. The dependent variable is the change in social spending between two elections as a percentage of a country GDP. The analysis includes 12 countries over the 1980-2016 period. Controls are not displayed. See Table D in the online appendix for the full table including control variables. 
The results in column (3), however, support our expectations associated with the number-of-parties hypothesis. As predicted, away $\Delta$ median citizen has a negative effect $(-0.44)$ while its interaction with \# of parties has a positive impact $(0.21)$ on $\Delta$ social spending - both effects are statistically significant at the 0.05 level. In order to get a better understanding of this impact we present in Figure 2 the corresponding marginal effect plot. As expected, Figure 2 shows that the marginal effect of away $\Delta$ median citizen is negative $(-0.23)$ and statistically significant at the 0.05 level when \# of parties equals 1 . This indicates that if the median citizen is moving to the right (left) by one unit on the left-right scale away from a single-party government to her left (right), social spending is adjusted downwards (upwards) by 0.23 points of percentage of a country GDP. However, the marginal effect of away $\Delta$ median citizen is not statistically different from 0 when \# of parties equals 2 or 3 . In these cases, coalition governments under PR systems do not adjust their spending in respect of a shift of the median citizen away from their position. Figure 2 also displays the distribution of the \# of parties under PR systems. Overall, about 33\% of the cabinets in PR systems are single-party governments.

On the other hand, it appears in Figure 2 that when \# of parties in government equals 4 (about $12 \%$ of PR governments) the marginal effect of away $\Delta$ median citizen is positive (0.39) and statistically significant at the 0.05 level. In terms of government responsiveness, this represents the worst answer that governments may provide to changes in citizens' ideological preferences. In effect, this is that governments are unresponsive to shifts in the position of the median citizen because they are changing their social spending in the opposite direction from what is expected. A reason that may explain this unexpected result relates to the finding in the political economy literature that public spending is generally

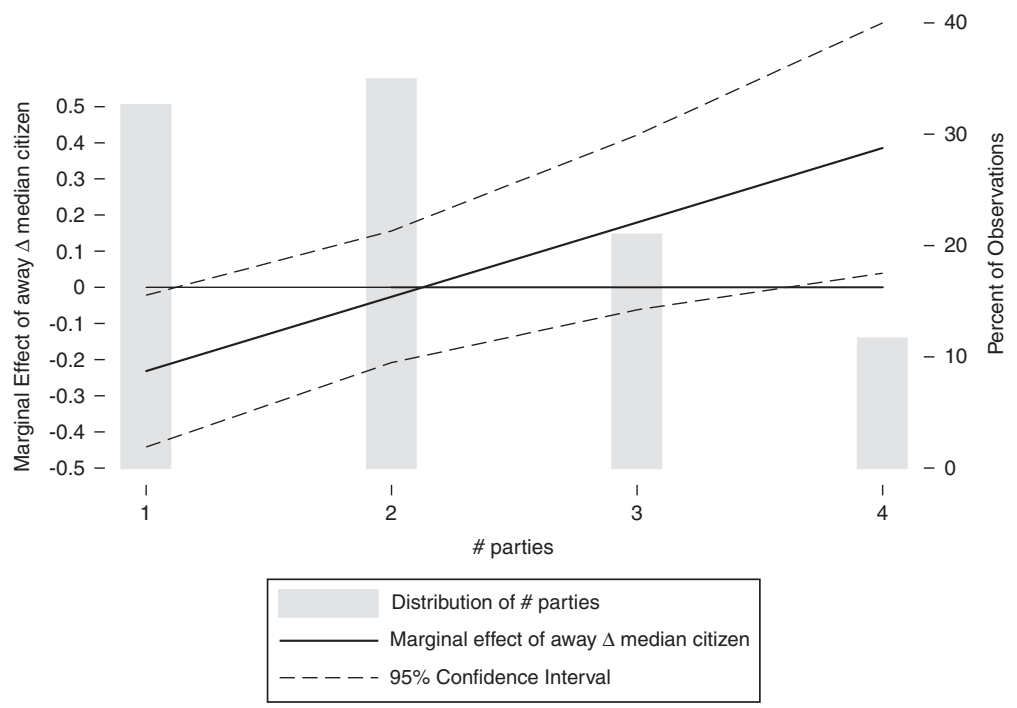

Figure 2. Marginal Effect of Away $\Delta$ Median Citizen on $\Delta$ in Social Spending as \# of Parties Changes under PR Systems 
pushed upwards as the number of parties in cabinet increases (Bawn and Rosenbluth 2006; Persson et al. 2007). As spending increases under these multiparty governments it is possible that citizens thermostatically adjust their position to the right as they prefer then a decrease in spending (Soroka and Wlezien 2010). As these two dynamics work simultaneously - spending is pushed upwards and citizens move to the right - it would produce the unexpected result found in Figure 2.

\section{Conclusion}

The empirical literature on government responsiveness to citizens' preferences has grown significantly over the last decade. Scholars, however, have omitted to clarify the concept of government responsiveness and its relationship to government congruence with citizens' preferences. This lack of conceptualization has meaningful implications for our expectations about whether governments are responsive to citizens' ideological preferences. In line with the claim of previous scholars (Adams et al. 2006, 2009; Kang and Powell 2010; McDonald and Budge 2005), we argued that when the median citizen is moving to the left (right) away from the government to her right (left), social spending should be adjusted upwards (downwards). Importantly, however, and in opposition with the claim of what we labelled the 'standard approach', we argued that when the median citizen is moving to the left (right) towards the government to her left (right), social spending should be adjusted downwards (upwards).

Interestingly, we showed that governments under majoritarian systems appear to adjust their social spending according to changes in the position of the median citizen that are away from governments, while this is less often the case on average under PR systems. With regard to government responsiveness under PR systems, we showed that only single-party governments respond to shifts in the position of the median citizen away from government positions. Otherwise, coalition governments are unresponsive to such changes. On the other hand, all types of governments do not adjust their social spending in accordance with changes in the position of the median citizen that are towards their position. On this account, governments under majoritarian and PR systems appear to be as much 'unresponsive'. This result is interesting given that it supports a view of parties as balancing vote-seeking and policy-seeking motivations while in office (Müller and Strøm 1999). We acknowledge above that we build our expectations on the assumption that parties - especially those forming governments - are mostly voteoriented. A pure vote-seeking party, however, would be converging on the median citizen even if the latter moves towards the party position. Our results suggest instead that other motivations may influence governments' decisions to be responsive (or not) and that policy objectives are likely one of them. Consequently, future work may want to integrate vote-seeking and policy-seeking motivations in mechanisms of party and government responsiveness.

Another factor that would be important to consider in future studies relates to the role of economic crises, and in particular the recent great recession, in conditioning government responses to public opinion. To our knowledge, no study has examined whether difficult economic times affect government responsiveness to 
public opinion. Given the thermostatic model of representation (Soroka and Wlezien 2010), we may expect public opinion to favour greater public spending as governments make cuts in the latter due to austerity measures. We might thus expect governments to be less responsive in these economic circumstances. This unresponsiveness could also have meaningful consequences on how citizens perceive their political system and how far they are satisfied with the way democracy works (Esaiasson et al. 2017; Ferland 2017b; Mayne and Hakhverdian 2017; Stecker and Tausendpfund 2016). These are important issues to consider in future work.

Overall, our conclusion about the impact of electoral systems is thus consistent with Soroka and Wlezien (2012), who show that governments under majoritarian systems are more responsive to changes in public opinion with respect to public spending. Taken together, our results based on different approaches to government responsiveness provide significant evidence of the advantages of majoritarian systems in making government outputs respond to citizens' preferences. In recent decades, many studies have argued for the superiority of PR systems for maximizing the citizen-elite connection through better representation of citizens in legislatures (Carey and Hix 2011; Golder and Stramski 2010; Lijphart 1984, 1999; Powell 2000). Our results cast a shadow over this optimistic picture. Even if citizens have a greater voice electorally under proportional electoral systems, our results indicate that these voices do not influence government policies to the same extent as under majoritarian systems.

Supplementary information. To view the supplementary material for this article, please visit https://doi.org/10.1017/gov.2018.47.

Acknowledgements. I wish to thank Elisabeth Gidengil, Stuart Soroka, André Blais, Matt Golder and the journal's reviewers for their helpful comments. I also thank the Canada's Social Sciences and Humanities Research Council (SSHRC) for its financial support.

\section{Notes}

1 A third possibility is that the median citizen stays in the same position. Note, however, that we did not find any occurrence of a median citizen staying in the same position in our data.

2 Note that this assumption holds whether we are interested in short-term or long-term responsiveness. 3 Note that in Hypotheses 3 and 4 'government responsiveness' refers to the two types of government responsiveness identified, respectively, in Hypotheses 1 and 2. Tsebelis's theory of veto players also predicts greater policy stability as the ideological distance of the veto players increases. We have examined the influence of ideological distance on government responsiveness but did not find any effect.

4 Note that we do not assume that the scores on the left-right ideological scale represent the same substantive position across countries. Different adjustments have been proposed to account for this issue e.g. see Best et al. (2012). Note, however, that these types of adjustment do not affect the distance between each score, which is the quantity of interest in this article. Consequently, even if the scores may represent different substantive positions across countries, we assume, as defended by Powell (2006: 296), that the distance between these scores represents the same substantive quantity.

5 We restrict the analysis to non-presidential democracies because the government formation process and the distribution of portfolios are different in presidential system (see Clark et al. 2009: 443-449). Switzerland is included in the analysis because the president does not have the power to replace the government, while important powers are assigned to the Swiss Federal Council. The results are substantively the same when we exclude Switzerland from the analysis.

6 Year at the beginning of a government mandate represents the year the government formed after the election and the year at the end of a government mandate represents the year of the (next) election. 
7 Note that the results are substantively the same whether we use the position of the median citizen or voter. We transform the scale to a 0-100 scale. We also apply Warwick's procedure (2010) and transform the respondents' left-right position into a continuous variable.

8 Note that we exclude from the analysis the observations when it is not possible to compute a government position due to a lack of information about a party's position in government.

9 To identify such changes, we use the European Representative Democracy (ERD) data archive (Andersson et al. 2012).

10 Some readers might wonder if an alternative approach to measure the positions of the median citizen is more appropriate. The main alternative would be to use the Comparative Manifesto Project data set and to rely on the methods proposed by Kim and Fording $(1998,2002)$. There are a number of concerns, however, associated with this measure (see Warwick and Zakharova 2013). This approach also raises an endogeneity problem because the position of the median voter in the Kim and Fording measure is inferred in part from the government position.

11 A negative coefficient of closer $\Delta$ median citizen would support the argument that governments take such opportunity to move presumably closer to their ideal point and further from the median citizen.

12 The data are available online: http://stats.oecd.org.

13 Note that disadvantageous should be included in the model given that it is part of closer and away $\Delta$ median citizen as indicated above.

14 The fact that New Zealand changed its electoral system in 1996 for a PR electoral system makes it possible to include $P R$ - a time-invariant variable - in the fixed-effects model. Note that the results are substantively the same when we exclude New Zealand. Note that it is possible to examine how a timeinvariant variable - as PR - conditions the impact of another variable in a fixed-effects model - see Andreass (2013: ch. 3).

\section{References}

Adams J (2012) Causes and Electoral Consequences of Party Policy Shifts in Multiparty Elections: Theoretical Results and Empirical Evidence. Annual Review of Political Science 15, 401-419.

Adams J, Clark M, Ezrow L and Glascow G (2006) Are Niche Parties Fundamentally Different from Mainstream Parties? The Causes and the Electoral Consequences of Western European Parties' Policy Shifts, 1976-1998. American Journal of Political Science 50, 513-529.

Adams J, Haupt AB and Stoll H (2009) What Moves Parties? The Role of Public Opinion and Global Economic Conditions in Western Europe. Comparative Political Studies 42, 611-639.

Andersson S, Bergman T and Ersson S (2012) The European Representative Democracy Data Archive. ed. Riksbankens Jubileumsfond (In2007-0149::1-E).

Andreass H-J, Golsch K and Schmidt A (2013) Applied Panel Data Analysis for Economic and Social Surveys. London: Springer.

Bakker R, Jolly S and Polk J (2012) Complexity in the European Party Space: Exploring Dimensionality with Experts. European Union Politics 13, 219-245.

Bawn K (1999) Money and Majorities in the Federal Republic of Germany: Evidence for a Veto Players Model of Government. American Journal of Political Science 43, 707-736.

Bawn K and Rosenbluth F (2006) Short Versus Long Coalitions: Electoral Accountability and the Size of the Public Sector. American Journal of Political Science 50, 251-265.

Best RE, Budge I and McDonald MD (2012) Representation as a Median Mandate: Taking CrossNational Differences Seriously. European Journal of Political Research 51, 1-23.

Blais A and Bodet M-A (2006) Does Proportional Representation Foster Closer Congruence between Citizens and Policy Makers? Comparative Political Studies 39, 1243-1262.

Brambor T, Roberts Clark W and Golder M (2006) Understanding Interaction Models: Improving Empirical Analyses. Political Analysis 14, 63-82.

Brooks C and Manza J (2006) Why Do Welfare States Persist? Journal of Politics 68, 816-827.

Carey JM and Hix S (2011) The Electoral Sweet Spot: Low-Magnitude Proportional Electoral Systems. American Journal of Political Science 55, 383-397.

Clarke HD, Golder M and Golder SN (2012) Principles of Comparative Politics. Washington DC: CQ Press. 
Cox GW (1997) Making Votes Count: Strategic Coordination in the World's Electoral Systems. Cambridge: Cambridge University Press.

Dahl RA (1971) Polyarchy: Participation and Opposition. New Haven: Yale University Press.

D'Alimonte R (1999) Party Behavior in a Polarized System: The Italian Communist Party and the Historic Compromise. In Müller WC and Strøm K (eds), Policy, Office, or Votes? How Political Parties in Western Europe Make Hard Decisions. Cambridge: Cambridge University Press, pp. 141-171.

Dalton RJ, Farrell DM and McAllister I (2011) Political Parties and Democratic Linkage. New York: Oxford University Press.

Downs A (1957) An Economic Theory of Democracy. New York: HarperCollins.

Durr RH (1993) What Moves Policy Sentiment? American Political Science Review 87, 158-170.

Enelow J and Hinich M (1984) The Spatial Theory of Voting. Cambridge: Cambridge University Press.

Erikson RS, Wright GC and McIver J (1989) Political Parties, Public Opinion, and State Policy in the United States. American Political Science Review 83, 729-750.

Erikson RS, MacKuen MB and Stimson JA (2002) The Macro Polity. Cambridge: Cambridge University Press.

Esaiasson P, Gilljam M and Persson M (2017) Responsiveness Beyond Policy Satisfaction: Does it Matter to Citizens? Comparative Political Studies 50, 739-765.

Ezrow L, De Vries C, Steenbergen M and Edwards E (2011) Mean Voter Representation and Partisan Constituency Representation: Do Parties Respond to the Mean Voter Position or to Their Supporters? Party Politics 17, 275-301.

Ferland B (2017a) The Alternative Specification of Interaction Models with a Discrete Modifying Variable. Political Methodologist 25, 11-15.

Ferland B (2017b) Retrospective Ideological Representation and its Impact on Democratic Satisfaction. Journal of Elections, Public Opinions and Parties 27, 192-212.

Fisher SD and Hobolt SB (2010) Coalition Government and Electoral Accountability. Electoral Studies 29, 358-369.

Franzese RJ Jr (2002) Macroeconomic Policies of Developed Democracies. Cambridge: Cambridge University Press.

Golder M and Stramski J (2010) Ideological Congruence and Electoral Institutions. American Journal of Political Science 54, 90-106.

Ha E (2008) Globalization, Veto Players, and Welfare Spending. Comparative Political Studies 41, 783-813.

Hobolt SB and Klemmensen R (2005) Responsive Government? Public Opinion and Government Policy Preferences in Britain and Denmark. Political Studies 53, 379-402.

Hobolt SB and Klemmensen R (2008) Government Responsiveness and Political Competition in Comparative Perspective. Comparative Political Studies 41, 309-337.

Huber JD (1989) Values and Partisanship in Left-Right Orientations: Measuring Ideology. European Journal of Political Research 17, 599-621.

Huber JD and Powell GB Jr (1994) Congruence between Citizens and Policymakers in Two Visions of Liberal Democracy. World Politics 46, 291-326.

Jessee SA (2012) Ideology and Spatial Voting in American Elections. Cambridge: Cambridge University Press.

Joesten DA and Stone WJ (2014) Reassessing Proximity Voting: Expertise, Party, and Choice in Congressional Elections. Journal of Politics 76, 740-753.

Kang S-G and Powell GB Jr (2010) Representation and Policy Responsiveness: The Median Voter, Election Rules, and Redistributive Welfare Spending. Journal of Politics 72, 1014-1028.

Kim HM and Fording RC (1998) Voter Ideology in Western Democracies, 1946-1989. European Journal of Political Research 33, 73-97.

Kim HM and Fording RC (2002) Government Partisanship in Western Democracies, 1945-1998. European Journal of Political Research 41, 187-206.

Kitschelt H (1994) The Transformation of European Social Democracy. New York: Cambridge University Press.

Kriesi H, Grande E, Frey T, Lachat R, Dolezal M and Bornschier S (2008) West European Politics in the Age of Globalization. Cambridge: Cambridge University Press.

Lijphart A (1984) Democracies: Patterns of Majoritarian and Consensus Government in Twenty-One Countries. New Haven: Yale University Press. 
Lijphart A (1999) Patterns of Democracy: Government Forms and Performance in Thirty-Six Countries. New Haven: Yale University Press.

Mansbridge J (2003) Rethinking Representation. American Political Science Review 97, 515-528.

Mayhew DR (1974) Congress: The Electoral Connection. New Haven: Yale University Press.

Mayne Q and Hakhverdian A (2017) Ideological Congruence and Citizen Satisfaction: Evidence from 25 Advanced Democracies. Comparative Political Studies 50, 822-849.

McDonald MD and Budge I (2005) Elections, Parties, Democracy: Conferring the Median Mandate. New York: Oxford University Press.

Müller WC and Strøm K (eds) (1999) Policy, Office, or Votes? How Political Parties in Western Europe Make Hard Decisions. Cambridge: Cambridge University Press.

Page BI and Shapiro RY (1983) Effects of Public Opinion on Policy. American Political Science Review 77, 175-190.

Persson T, Roland G and Tabellini G (2007) Electoral Rules and Government Spending in Parliamentary Democracies. Quarterly Journal of Political Science 2, 155-188.

Pitkin HF (1967) The Concept of Representation. Berkeley: University of California Press.

Powell GB Jr (2000) Elections as Instruments of Democracy: Majoritarian and Proportional Visions. New Haven: Yale University Press.

Powell GB Jr (2004) The Chain of Responsiveness. Journal of Democracy 15, 91-105.

Powell GB Jr (2006) Election Laws and Representative Governments: Beyond Votes and Seats. British Journal of Political Science 36, 291-315.

Powell GB Jr and Whitten GD (1993) A Cross-National Analysis of Economic Voting: Taking Account of the Political Context. American Journal of Political Science 37, 391-414.

Przeworski A, Stokes SC and Manin B (eds) (1999) Democracy, Accountability, and Representation. Cambridge: Cambridge University Press.

Soroka SN and Wlezien C (2010) Degrees of Democracy: Politics, Public Opinion, and Policy. Cambridge: Cambridge University Press.

Stecker C and Tausendpfund M (2016) Multidimensional Government-Citizen Congruence and Satisfaction with Democracy. European Journal of Political Research 55, 492-511.

Stimson JA, MacKuen MB and Erikson RS (1995) Dynamic Representation. American Political Science Review 89, 543-565.

Swank DH (2006) Electoral, Legislative, and Government Strength of Political Parties by Ideological Group in Capitalist Democracies, 1950-2006: A Database. www.marquette.edu/polisci/documents/part19502006 codeupd.pdf.

Tsebelis G (2002) Veto Players: How Political Institutions Work. Princeton: Princeton University Press.

Tsebelis G and Chang ECC (2004) Veto Players and the Structure of Budgets in Advanced Industrialized Countries. European Journal of Political Research 43, 449-476.

Warwick PV (2010) Bilateralism or the Median Mandate? An Examination of Rival Perspectives on Democratic Governance. European Journal of Political Research 49, 1-24.

Warwick PV and Zakharova M (2013) Measuring the Median: The Risks of Inferring Beliefs from Votes. British Journal of Political Science 43, 157-175.

Wittman D (1977) Candidates with Policy Preferences: A Dynamic Model. Journal of Economic Theory 14, $180-189$.

Wittman D (1983) Candidate Motivation: A Synthesis of Alternative Theories. American Political Science Review 77, 142-157.

Wlezien C and Soroka SN (2012) Political Institutions and the Opinion-Policy Link. West European Politics 35, 1407-1432.

Wlezien C and Soroka SN (2015) Electoral Systems and Opinion Representation. Representation 51, $273-285$.

Wright GC (1976) Linear Models for Evaluating Conditional Relationships. American Journal of Political Science 2, 349-373.

Cite this article: Ferland B. 2020. Government Responsiveness under Majoritarian and (within) Proportional Electoral Systems. Government and Opposition: An International Journal of Comparative Politics

55: 595-616, doi:10.1017/gov.2018.47 